\title{
Sister chromatid exchange analysis in lymphocytes of workers exposed to hexavalent chromium
}

\author{
T NAGAYA, ${ }^{1}$ N ISHIKAWA,${ }^{2}$ H HATA ${ }^{2}$ \\ From the Department of Public Health, 'Gifu University School of Medicine, Gifu-shi 500, and Gifu Labour \\ Standards Association, ${ }^{2}$ Gifu-shi 501-61, Japan
}

ABSTRACT To investigate the usefulness of sister chromatid exchange (SCE) analysis in lymphocytes $\vec{\omega}$ as an indicator for mutagenic effects after in vivo exposure to hexavalent chromium (Cr), SCEO frequency was analysed in lymphocytes of $44 \mathrm{Cr}$ platers occupationally exposed to hexavalent $\mathrm{Cr}$ and 47 controls. Although urinary $\mathrm{Cr}$ analysis confirmed that the $\mathrm{Cr}$ platers were exposed to $\mathrm{Cr}$, no effects of the exposure on SCE frequency were found. Smokers, both $\mathrm{Cr}$ platers and controls, had $\dot{a}$ significantly higher SCE frequency than non-smokers. These results suggest that SCE analysis in ${ }_{\infty}^{+}$ human lymphocytes is not a good indicator of possible mutagenic effects of exposure to hexavalente Cr.

Hexavalent chromium $(\mathrm{Cr})$ is mutagenic in the Ames test and other tests in vitro ${ }^{12}$ and carcinogenic in experimental animals in vivo. ${ }^{3} \mathrm{Cr}$ compounds are widely used in various industries and epidemiological studies have indicated a high incidence of lung cancer among workers occupationally exposed to hexavalent $\mathrm{Cr}$ compounds. ${ }^{4}$ If the hexavalent $\mathrm{Cr}$ is highly soluble, such as chromic acid in $\mathrm{Cr}$ plating, there seems to be an increased risk also for cancer in other organs. ${ }^{5}$

Since SCE analysis is a sensitive means of detecting DNA damage, many investigators have used SCE analysis in lymphocytes for monitoring human populations for exposure to environmental mutagens. ${ }^{6}$ The usefulness of SCE analysis in such monitoring studies, however, is obscure. For example, many studies have been published on the effects of smoking habits on SCE frequency in human lymphocytes ${ }^{7-9}$ because tobacco is one of the most common sources of mutagens in our daily living. The results in these studies, however, are contradictory. ${ }^{10}$ Although hexavalent $\mathrm{Cr}$ induces SCEs in human cultured cells in vitro, ${ }^{12}{ }^{13}$ previous studies among workers exposed to $\mathrm{Cr}$ give contradictory results. Some investigators reported that lymphocytes of workers exposed to $\mathrm{Cr}$ in electroplating factories had a higher SCE frequency than those of controls, ${ }^{14}{ }^{15}$ whereas others found no increase in SCE frequency in the lymphocytes of stainless steel welders exposed to $\mathrm{Cr}{ }^{16}{ }^{17}$

Thus to investigate the usefulness of SCE analysis in lymphocytes as an indicator for mutagenic effects after in vivo exposure to hexalavent $\mathrm{Cr}, \mathrm{SCE}$ frequency was

Accepted 14 December 1987 analysed in lymphocytes of $\mathrm{Cr}$ platers occupationally exposed to hexavalent $\mathrm{Cr}$ in air $^{18}$ and controls.

\section{Material and methods}

\section{SUBJECTS}

The subjects were 44 male $\mathrm{Cr}$ platers and 47 mo controls. The $\mathrm{Cr}$ platers had been constantly engaged in hard $\mathrm{Cr}$ plating. There was a pungent odour nea the baths. Some of the platers used both gloves an $\mathbb{B}$ masks when working but others used only gloves $\overrightarrow{\vec{\sigma}}$ Their duration of employment was $0.5-30.7$ years (range), averaging 13.8 \pm 8.7 years (mean $\pm \mathrm{SD}$ ) Controls were various workers who had not been? exposed to $\mathrm{Cr}$ compounds or any other harmfub agents. To analyse the effects of exposure to $\mathrm{Cr}$ or SCEs independently from those of smoking habits each subject was classified into "non-smokers" op. "smokers." The subjects referred to as non-smoker. had not smoked for at least the past two years. Each os the smokers smoked 5-60 cigarettes a day every dayo Finally, we had four groups: 14 non-smoking $C$ ? platers, 30 smoking $\mathrm{Cr}$ platers, 21 non-smoking con厄 trols, and 26 smoking controls. The data on age, sex smoking habits, and employment of the subjects were based on personal interview.

SCE ANALYSIS

Venous blood was taken from each subject during working time on weekdays using heparinisect vacutainer tubes. Whole blood $(0.2 \mathrm{ml})$ was added? within six hours of sampling to minimum essential medium ( $3 \mathrm{ml}$ ) supplemented with $10 \%$ fetal bovines 
serum, $2 \%$ PHA-M, $13 \mu \mathrm{mol} / 1$ 5-bromodeoxyuridine, $1.5 \times 10^{5} \mathrm{U} / 1$ penicillin $G$ and $0.2 \mathrm{mmol} / 1$ streptomycin. Cultures were incubated in the dark for 68 hours at $37^{\circ} \mathrm{C}$. After treatment with colcemid $(0.3 \mu \mathrm{mol} / 1)$ for three hours at the end of culture, microscope slides were prepared by a conventional method and stained by the FPG technique. ${ }^{19}$ SCEs were counted in 25 cells containing 46 chromosomes in each preparation and the mean SCE frequency was calculated as SCEs per cell for each subject.

\section{URINARY CR ANALYSIS}

Urinary $\mathrm{Cr}$ was analysed as a measure of the degree of exposure. Urine was collected from each subject simultaneously with the blood sampling and was stored at $-20^{\circ} \mathrm{C}$ before analysis. $\mathrm{Cr}$ was analysed by a direct flameless atomic absorption spectrophotometric method and the $\mathrm{Cr}$ concentration in urine was calculated by the standard addition method. Triplicate analyses were done and the mean was obtained in each sample. The coefficient of variation was $5.3 \%$ for ten measurements of the same sample. The lowest detectable level by the method was $0.04 \mu \mathrm{mol} \mathrm{Cr} / 1$ urine.

\section{STATISTICAL ANALYSIS}

Students $t$ test and the linear correlation coefficient test

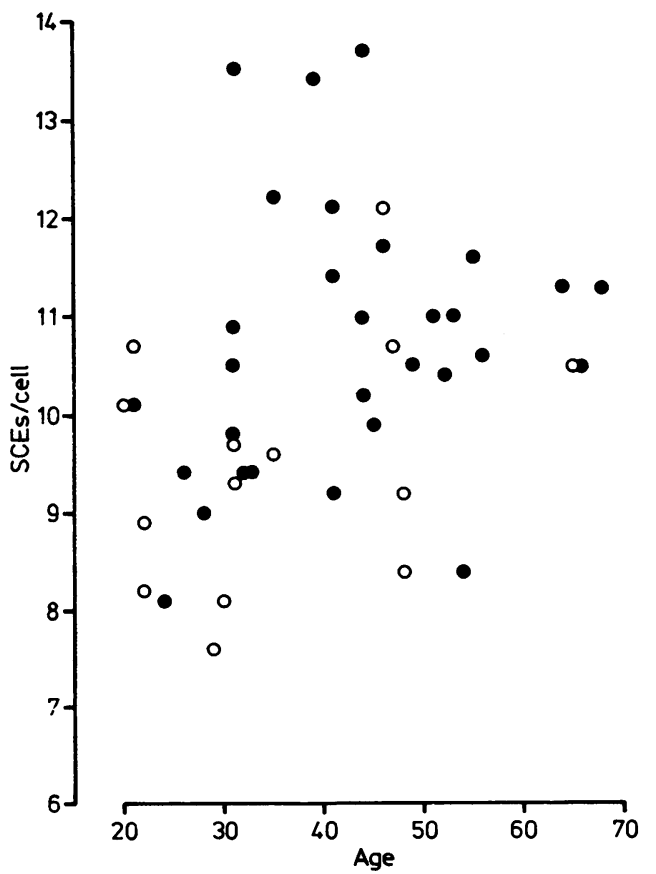

Fig 1 Relation between SCE frequency and age of $44 \mathrm{Cr}$ platers: $\bigcirc$ non-smokers, smokers. were used. Statistical significance denotes $\mathrm{p}<0.05$. All tests were two sided.

\section{Results}

No significant correlation was found between the SCE frequency of each subject and their age in either the $\mathrm{Cr}$ platers or the controls (figs 1 and 2).

The mean SCE frequencies for non-smoking and smoking Cr-platers were 9.5 SCEs/cell and 10.7 SCEs/ cell respectively, and those for corresponding nonsmoking and smoking controls were 9.4 SCEs/cell and 10.7 SCEs/cell respectively (table). No differences between the mean SCE frequencies for $\mathrm{Cr}$ platers and corresponding controls could be shown. The mean SCE frequencies for smokers in both the $\mathrm{Cr}$ platers and the controls, however, were statistically higher than those for non-smokers.

The urinary $\mathrm{Cr}$ concentration of the platers ranged from $0.05 \mu \mathrm{mol} / 1$ to $1.54 \mu \mathrm{mol} / 1$ with a mean of $0.25 \mu \mathrm{mol} / \mathrm{l} ; \mathrm{Cr}$ was not detected in the urine of the controls. No significant correlation between SCE frequency of $\mathrm{Cr}$ platers and their urinary $\mathrm{Cr}$ concentration was observed in non-smoking or smoking $\mathrm{Cr}$ platers (fig 3).

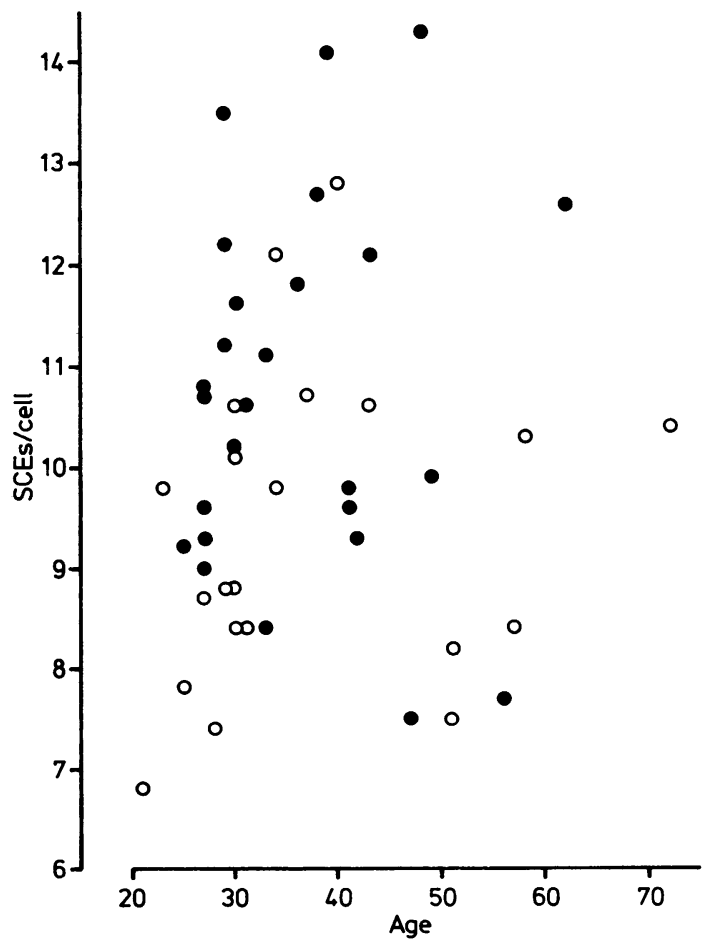

Fig 2 Relation between SCE frequency and age of 47 controls: $\bigcirc$ non-smokers, smokers. 
Age, smoking habits, urinary $C r$ and SCE frequency of Cr platers and controls

\begin{tabular}{|c|c|c|c|c|c|c|c|c|c|c|}
\hline & & \multirow[b]{2}{*}{ No } & \multicolumn{2}{|c|}{ Age (years) } & \multicolumn{2}{|c|}{ Cigarettes smoked a day } & \multicolumn{2}{|c|}{ Urinary $\mathrm{Cr}(\mu \mathrm{mol} / \mathrm{l})$} & \multicolumn{2}{|c|}{ SCEs/cell } \\
\hline & & & Range & $M e a n \pm S D$ & Range & $M e a n \pm S D$ & Range & $M e a n \pm S D$ & Range & Mean $\pm S \mathscr{P}$ \\
\hline $\begin{array}{l}\mathrm{Cr} \text { platers } \\
\text { Controls }\end{array}$ & $\begin{array}{l}\text { Non-smoking } \\
\text { Smoking } \\
\text { Non-smoking } \\
\text { Smoking }\end{array}$ & $\begin{array}{l}14 \\
30 \\
21 \\
26\end{array}$ & $\begin{array}{l}20-65 \\
21-68 \\
21-72 \\
25-62\end{array}$ & $\begin{array}{l}34 \cdot 5 \pm 13 \cdot 5 \\
42 \cdot 5 \pm 12 \cdot 5 \\
37 \cdot 2 \pm 13 \cdot 4 \\
36 \cdot 4 \pm 9 \cdot 9\end{array}$ & $\begin{array}{l}\overline{10-40} \\
5-60\end{array}$ & $\begin{array}{l}\overline{20} \cdot 0 \pm 9 \cdot 2 \\
\overline{24} \cdot 3 \pm 12 \cdot 9\end{array}$ & $\begin{array}{l}0.06-0.47 \\
0.05-1.54 \\
-\end{array}$ & $\begin{array}{l}0 \cdot 18 \pm 0 \cdot 13 \\
0 \cdot 29 \pm 0 \cdot 31 \\
-\end{array}$ & $\begin{array}{l}7 \cdot 6-12 \cdot 1 \\
8 \cdot 1-13 \cdot 7 \\
6 \cdot 8-12 \cdot 8 \\
7 \cdot 5-14 \cdot 3\end{array}$ & $\begin{array}{r}9.5 \pm 1.2 \overline{\mathrm{s}} \\
10.7 \pm 1.4 \overline{\mathrm{O}} \\
9.4 \pm 1.6 \\
10.7 \pm 1.8 \mathrm{O}\end{array}$ \\
\hline
\end{tabular}

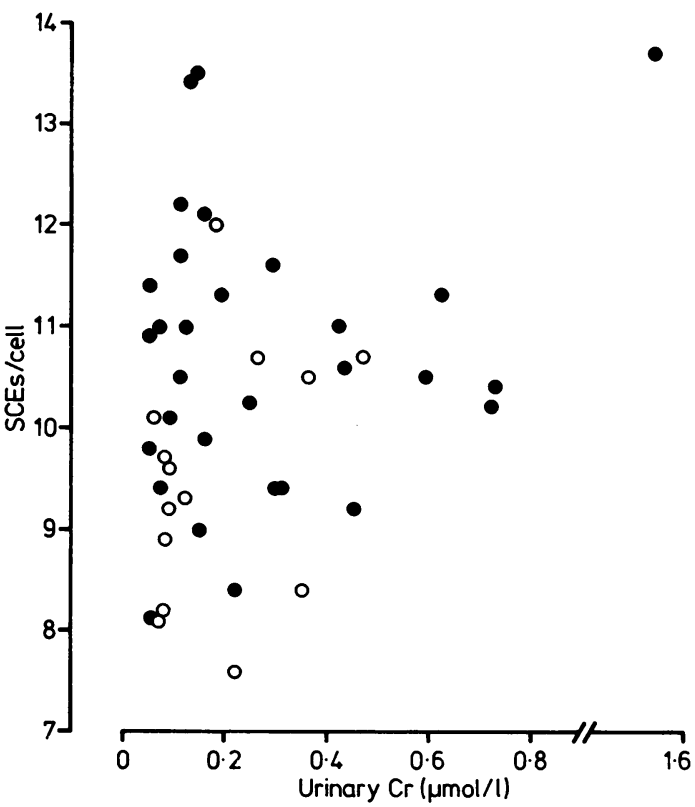

Fig 3 Relation between SCE frequency and urinary $\mathrm{Cr}$ concentration of 44 Cr platers: $\bigcirc$ non-smokers, $\bigcirc$ smokers.

\section{Discussion}

The independency of SCE frequency in lymphocytes from the age of the donors in this study (figs 1 and 2) is consistent with the results of our previous report. ${ }^{20}$ Thus we neglected the effects of age on SCE frequency in analysing the influence of exposure to $\mathrm{Cr}$ and smoking habits on SCE frequency.

Although the urinary $\mathrm{Cr}$ analysis suggests that the $\mathrm{Cr}$ platers were obviously exposed to $\mathrm{Cr}$, the exposure had no effect on SCE frequency. The SCE frequency in human cultured lymphocytes was increased from $15.5 \mathrm{SCEs} /$ cell to $20.4 \mathrm{SCEs} /$ cell by exposure to $10^{-7}$ $\mathrm{M} \mathrm{C}_{\mathrm{r} 2} \mathrm{O}_{7}{ }^{2-}$ in the culture medium, ${ }^{13}$ a concentration of $\mathrm{Cr}_{2} \mathrm{O}_{7}{ }^{2-}$ equivalent of $0.20 \mu \mathrm{mol} \mathrm{Cr} / \mathrm{l}$. On the other hand, the urinary $\mathrm{Cr}$ concentration of the $\mathrm{Cr}$ platers ranged from 0.05 to $1.54 \mu \mathrm{mol} / 1$ with a mean of $0.25 \mu \mathrm{mol} / 1$. Since the concentration of substance in plasma is generally much lower than that in the urine, the $\mathrm{Cr}$ concentration in plasma of the $\mathrm{Cr}$ platers ma\% simply be too low to increase the SCE frequency. Moreover, hexavalent $\mathrm{Cr}$ is easily trapped by cells and after being trapped by cells, hexavalent $\mathrm{Cr}$ is easily reduced to trivalent $\mathrm{Cr}^{21}{ }^{22}$ which has little muta genicity or SCE inducing ability. ${ }^{123}$ These finding 8 suggest that inhaled hexavalent $\mathrm{Cr}$ cannot easily reaç the lymphocytes in man. The exposure level of the $C$ platers may be too low to give hexavalent $\mathrm{Cr}$-exposureto lymphocytes.

Two previous SCE studies among workers expose $\phi$ to $\mathrm{Cr}^{1415}$ indicate an increase of SCE frequency by $\mathrm{Cr}=$ exposure, whereas two other studies were negative. ${ }^{16}$ th Three of the four studies also analysed urinary $\mathrm{Cr}$ of workers; $2-32 \mu \mathrm{g} \mathrm{Cr} / \mathrm{g}$ creatinine, ${ }^{15} 0 \cdot 2-1 \cdot 55 \mu \mathrm{mol} \mathrm{Cr}$ 座 urine, ${ }^{16}$ and $5-155 \mu \mathrm{mol} \mathrm{Cr} / \mathrm{mol}$ creatinine ${ }^{17}$; the urin $=$ ary $\mathrm{Cr}$ concentration in our $\mathrm{Cr}$ platers was $0.05 \overline{0}$ $1.54 \mu \mathrm{mol} \mathrm{Cr} / 1$ urine. There is no major differegce between these values and suggest that the degreofot exposure to $\mathrm{Cr}$ was similar in all the studies. Thes results, however, were contradictory and seem 귕ㅎㅁ depend on the effects of smoking on SCEs. Since smoking is probably one of the most effective factor influencing SCE frequency in human lymphocytes, $\stackrel{24}{\rightarrow}$ we have to analyse effects of exposure to $\mathrm{Cr}$ on SCES independently from those of smoking habits. Only two previous SCE studies in workers exposed to $\mathrm{Cr}$ have analysed effects of smoking habits on SCEs. ${ }^{16}{ }^{17}$ These studies, like ours, indicate that exposure to $\mathrm{Cr}$ does noo influence SCE frequency but that smoking increase $\bar{\AA}$ SCE frequency. Two other SCE studies in workers exposed to $\mathrm{Cr}$ with positive results have no analysis of smoking. ${ }^{14}$ is The results in the studies are possible confounded by smoking.

The results in this study suggest that SCE frequenc in human lymphocytes is not a good indicator for the mutagenic effects of in vivo exposure to hexavalent $C$ r Further population analysis studies are requiredu before SCE frequency can be used as a mutagenic indicator in human populations.

\section{References}

1 Bianchi V, Celotti L, Lanfranchi G, et al. Genetic effects of chromium compounds. Mutat Res 1983;117:279-300.

2 Venier P, Montaldi A, Majone F, Bianchi V, Lewis AG. Cytotoxic 
mutagenic and clastogenic effects of industrial chromium compounds. Carcinogenesis 1982;3:1331-8.

3 Langard S. The carcinogenicity of chromium compounds in man and animals. In: Burrows D, ed. Chromium: metabolism and toxicity. Baton Rouge, Florida: CRC Press, 1983:13-30.

4 Baetjer AM. Pulmonary carcinoma in chromate workers. Incidence on basis of hospital records. Archives of Industrial Hygiene and Occupational Medicine 1950;2:505-16.

5 Royle H. Toxicity of chromic acid in the chromium plating industry (1). Environ Res 1975;10:39-53.

6 Lambert B, Lindblad A, Holmberg K, Francesconi D. The use of sister chromatid exchange to monitor human populations for exposure to toxicologically harmful agents. In: Wolff S, ed. Sister chromatid exchange. New York: Wiley-Interscience, 1982:149-82.

7 Lambert B, Lindblad A, Nordenskjöld M, Werelius B. Increased frequency of sister chromatid exchanges in cigarette smokers. Hereditas 1978;88:147-9.

8 Murthy PBK. Frequency of sister chromatid exchanges in cigarette smokers. Hum Genet 1979;52:343-5.

9 Husum B, Wulf HC, Niebuhr E. Sister chromatid exchange frequency correlates with age, sex and cigarette smoking in a 5year material of 553 healthy adults. Hereditas 1986;105:17-21.

10 Ardito G, Lamberti L, Ansaldi E, Ponzetto P. Sister-chromatid exchange in cigarette-smoking human females and their newborns. Mutat Res 1980;78:209-12.

11 Hedner K, Högstedt B, Kolnig A-M, Mark-Vendel E, Strömbeck B, Mitelman. Sister chromatid exchanges and structural chromosome aberrations in relation to smoking in 91 individuals. Hereditas 1983;98:77-81.

12 Macrae WD, Whiting RF, Stich HF. Sister chromatid exchanges induced in cultured mammalian cells by chromate. Chem Biol Interact 1979;26:281-6.

13 Andersen O, Wulf HC, Røssonne M, Nordberg GF. Effects of metals on sister chromatid exchange in human lymphocytes and Chinese hamster V79-E cells. In: Prevention of occupational cancer. (ILO occupational safety and health series, vol 46.) Genoa: International Labour Office, 1982:491-501.

14 Stella M, Montaldi A, Rossi R, Rossi G, Levis AG. Clastogenic effects of chromium on human lymphocytes in vitro and in vivo. Mutat Res 1982;101:151-64.

15 Sarto F, Cominato I, Bianchi V, Levis AG. Increased incidence of chromosomal aberrations and sister chromatid exchanges in workers exposed to chromic acid $\left(\mathrm{CrO}_{3}\right)$ in electroplating factories. Carcinogenesis 1982;9:1011-6.

16 Husgafvel-Pursiainen K, Kalliomäki P-L, Sorsa M. A chromosome study among stainless steel welders. J Occup Med 1982;24:762-6.

17 Littorin M, Hogstedt B, Stromback B, et al. No cytogenetic effects in lymphocytes of stainless steel welders. Scand $J$ Work Environ Health 1983;9:259-64.

18 Stern RM. Chromium compounds: production and occupational exposure. In: Langard S, ed. Biological and environmental aspects of chromium. Amsterdam: Elsevier, 1982:5-47.

19 Perry P, Wolff S. New Giemsa methods for the differential staining of sister chromatids. Nature 1974;251:156-8.

20 Nagaya T, Toriumi H. Spontaneous and induced sister chromatid exchanges in lymphocytes of healthy persons. Environ Res 1986;40:181-7.

21 Gray SJ, Sterling K. The tagging of red cells and plasma proteins with radioactive chromium. $J$ Clin Invest 1950;29:1604-13.

22 Rajam PC, Jackson AL. Distribution and valence state of radiochromium in intracellularly labelled Ehrlich mouse ascites carcinoma cells. Proc Soc Exp Biol Med 1958;99:210-3.

23 Nakamuro K, Yoshikawa K, Sayato Y, Kurata H. Comparative studies of chromosomal aberration and mutagenicity of trivalent and hexavalent chromium. Mutat Res 1978;58:175-81.

24 Watanabe T, Endo A. The SCE test as a tool for cytogenetic monitoring of human exposure to occupational and environmental mutagens. In: Tice RR, Hollaender A, eds. Sister chromatid exchange: 25 years of experimental research. New York: Plenum, 1984:939-55.

\section{Correspondence and editorials}

The British Journal of Industrial Medicine welcomes correspondence relating to any of the material appearing in the journal. Results from preliminary or small scale studies may also be published in the correspondence column if this seems appropriate. Letters should be not more than 500 words in length and contain a minimum of references. Tables and figures should be kept to an absolute minimum. Letters are accepted on the understanding that they may be subject to editorial revision and shortening.

The journal now also publishes editorials which are normally specially commissioned. The Editor welcomes suggestions regarding suitable topics; those wishing to submit an editorial, however, should do so only after discussion with the Editor. 